\title{
Determinants of the green electricity tariff uptake in the UK
}

Ronnie MacPherson

Ian Lange

Stirling Economics Discussion Paper 2012-11

May 2012

Online at

http://www.management.stir.ac.uk/research/economics/workingpapers 


\title{
Determinants of the green electricity tariff uptake in the UK*
}

\author{
Ronnie MacPherson \\ Division of Economics \\ University of Stirling \\ Stirling FK9 4LA \\ ronniemacp@gmail.com
}

\author{
lan Lange \\ Division of Economics \\ University of Stirling \\ Stirling FK9 4LA \\ +44(0) 1786467276 \\ i.a.lange@stir.ac.uk \\ (Corresponding Author)
}

\begin{abstract}
A number of countries offer domestic consumers the option of buying their electricity supply through a 'green tariff', whereby the supplier typically guarantees that all or part of the supply has been generated using renewable energy sources. Various studies have sought to identify variables describing and/or predicting why domestic consumers choose to purchase a green tariff. This study builds on previous work by reviewing the UK market in particular. Using data from the Understanding Society Survey (USS), a number of variables were tested for their predictive power. This included variables identified as statistically significant within other studies, and variables that - to the authors' knowledge - have not been tested through other work. Results find that individuals in the highest income quartile, those with higher qualifications, those supporting the Green political party, those exhibiting strong environmental behaviour and those households not in receipt of winter fuel payments were all more likely to have purchased green tariffs. Significant to a lesser degree were strong environmental attitudes and those households with some form of renewable energy technology installed.
\end{abstract}

JEL Codes: Q4, Q5, H4, L94

Keywords: Green Tariff; Environmental Attitudes and Behaviours; Household Decision Making

\footnotetext{
* The authors wish to thank Mirko Moro, Liam Delaney, and seminar participants at the Division of Economics at the University of Stirling for their helpful suggestions.
} 


\section{Introduction}

Many energy industry forecasts project a considerable increase in the contribution of renewable energy technologies (RETs) to global energy supply (e.g. BP, 2012).

Green (2011) is one of many authors suggesting that this trend is primarily explained by international efforts aiming to tackle climate change through reduced greenhouse gas emissions: RETs such as wind or solar power offer an obvious route for 'decarbonising' the fossil-fuel intensive electricity sector.

Government projections and targets further illustrate the trend towards increased RET capacity. For example, in order to meet its own targets the UK Government anticipates 15\% annual growth in RET capacity between 2010 and 2020 (DECC, 2011). This is not atypical: many other countries project similar trajectories (IEA, 2011). Clearly, a considerable volume of investment will be required to develop the infrastructure necessary to achieve such targets. To that end, various policies have been introduced to attract capital towards RETs: the UK's Renewables Obligation and the EU's Renewables Directive are two high-profile examples of such initiatives. While these policies tend to be aimed at energy suppliers and investors, they do not directly involve or incentivise domestic consumers.

Green tariffs offer one route through which domestic consumers can demonstrate support for - and contribute towards - investment in RETs: when a consumer purchases a green tariff the electricity supplier guarantees that all or part of the supply has been generated using RETs. Within the UK, green tariffs initially arose in the wake of electricity market deregulation (Batley et al, 2001). Suppliers established green tariffs partly to raise finance for the development of RETs, partly to help meet statutory targets, and - of most relevance to this research - partly as a response to consumer demand. As Graham (2007, p.2) suggests, green tariffs allow consumers to express their preferences for RETs and are ultimately "...one of the simplest ways for households to reduce their environmental impact".

However the work of Graham (2007) and the Green Energy Supply Certification Scheme ${ }^{1}$ implies that - for the majority of suppliers - green tariffs have principally been used to help energy companies fulfil their statutory requirements under the UK's Renewables Obligation and the EU's Renewables Directive. This latter approach has proved controversial: some have found it unpalatable that energy companies have used green tariffs to offset their legal obligations, rather than using the income to develop additional renewable infrastructure, above and beyond their statutory requirements (Graham, 2007; Friends of the Earth, 2005; BBC, 2008). In addition to these concerns about the legitimacy of green tariffs, it is clear that actual uptake of green tariffs has largely failed to match potential uptake: Graham (2007) compares a survey indicating that $64 \%$ of the UK population would consider purchasing a green tariff with data suggesting that less than $1 \%$ of the UK population actually purchase a green tariff. Why is there such a large discrepancy between stated consumer preferences and actual uptake? This research attempts to answer that question by analysing a large survey of the UK population.

\footnotetext{
${ }^{1}$ http://www.greenenergyscheme.org: independent, Ofgem-endorsed certification scheme for green tariffs in the UK
} 


\section{Literature review}

The quantity of research conducted into green tariff adoption is comparatively limited at present, partly explained through the relative infancy of the market: as Ozaki (2011) notes, the earliest green tariffs only arose in the mid-1990s, with still relatively few national markets offering the product.

\subsection{Previous frameworks, models and approaches}

While all studies are unified in their classification of green tariffs as a consumer product, there is divergence across the various theoretical frameworks as to what the primary influences are on consumer choice when selecting products (or expressing preferences), with these differences inevitably influencing the various hypotheses and models adopted in each study. For example, Hansla et al (2007) start with a theoretical assumption that green tariff adoption is a signal of value oriented consumer behaviour - in this instance pro-environmental behaviour. Consequently, their research looks most closely at the values, beliefs and attitudes of their sample. In contrast, Arkesteijn \& Oerlemans (2005) apply a quite different framework, with far broader starting assumptions that delink the specifics of the product. Instead of treating green tariffs in a more generalised fashion, their model is built around a conception of green tariffs as an innovation, rather than a product with predefined characteristics (whether 'pro-environmental' or otherwise). This higher level of abstraction allows for a model that looks at more general consumer variables in addition to environmental attitudes and behaviours.

Regardless of these theoretical differences, the majority of studies are predictive in nature, adopting contingent valuation methodology - and more specifically willingness-to-pay (WTP) - as the core tool. Only Kotchen \& Moore (2007) and Ozaki (2011) differ in their approaches, applying descriptive models and collating data through surveys without application of WTP. In all studies the data is interrogated via multivariate regressions, with the dependent variable being 'adoption of green tariff' or a variation thereof. A final commonality across studies is the relatively limited nature of the data sets - samples are characterised by both a small number of observations and a constrained geographical reach.

It is important to acknowledge that the theories and methodologies applied within these studies have not arisen in isolation. Studies into green consumerism more broadly (i.e. not just electricity) start appearing regularly during the mid-1990s. These studies - for example, Shrum et al (1995) and Mainieri et al (1997) - tend to start with an assumed relationship between environmental attitudes and green purchasing behaviour, but also explore broader demographic aspects, with their approaches and findings arguably laying some important foundations for future studies. In summary, it is clear that the existing green tariff research is based on similar assumptions, theoretical foundations and practical methodologies applied within research into green consumerism more broadly.

\subsection{Previous findings}

Despite the limited number of studies there is a degree of consistency across the work. A number of variables are consistently statistically significant when it comes to describing or predicting uptake of green tariffs. Perhaps unsurprisingly, several authors (e.g. Diaz-Rainey \& Ashton, 2008; Kotchen \& Moore, 2007; Arkesteijn \& Oerlemans, 2005) have found that consumers exhibiting greater concern for the 
environment are more likely to express an interest in buying green tariffs. In isolation this may seem obvious, but it's more interesting when combined with the finding that strong environmental concern alone is not sufficient for actual uptake. Other conditions need to be met before consumers with a supportive attitude actually purchase a green tariff. Indeed, this is what the work of psychologist and sociologists would suggest (Ajzen \& Fishbein, 1980; Kollmuss \& Agyeman, 2002). Attitudes are generally not very good predictors of behaviour, especially when the attitude (care about the environment) is not the same as the behaviour in question (what type of electricity to purchase).

Although previous studies are in agreement on the inadequacy of 'environmental concern' as a predictor, the studies are less consistent when it comes to isolating the other variables that influence uptake. Most promisingly - and again, perhaps unsurprisingly - consumers that have prior knowledge of renewable electricity or green tariffs are more likely to adopt: three studies identify this variable as significant (Diaz-Rainey \& Ashton, 2008; Arkesteijn \& Oerlemans, 2005; Ozaki, 2011). There is markedly less agreement around the demographics of green tariff adopters - for instance, Diaz-Rainey \& Ashton identify income as significant within the UK market, but Arkesteijn \& Oerlemans (2005) do not identify this significance in the Dutch market, and Kotchen \& Moore (2007) also note a lack of clear evidence for this in the US market. Studies looking into more detail around demographics (Diaz-Rainey \& Ashton, 2008; Kotchen \& Moore, 2007) do find agreement on variables that are not significant: age, gender and education demonstrate no significance within these authors' models.

Finally, it is interesting to note that a central contradiction of consumer behaviour towards green tariffs - namely the large discrepancy between stated interest in the product and actual uptake - is repeated across analogous product groups. A representative study is provided by Carrington et al (2010), who explore this 'intention-behaviour gap' in detail, finding a similar pattern amongst consumers exposed to 'ethical' purchasing decisions.

\subsection{Knowledge gaps}

The literature review demonstrates some agreement across existing studies into which variables describe and predict green tariff uptake. Additional research will certainly help to deepen this understanding, potentially contributing towards a firmer consensus on green tariff consumer characteristics.

However, it could be argued that the knowledge gaps are more fundamental than lack of agreement around explanatory variables. The existing studies are characterised by comparatively limited sample sizes, often only undertaken in a single city: the interrogation of a larger data set could improve accuracy and robustness of findings. Additionally, the number of variables explored tends to be limited: while some studies move away from looking merely at environmental preferences and behaviours, there is clear potential for broader exploration of demographic and economic characteristics.

Finally, all the studies were undertaken using surveys and data sets that were developed specifically for the analysis of green tariff adoption: consequently - and from a behavioural economics perspective - all these surveys could suffer from the 
framing effects first hypothesised by Tversky and Kahneman (1981). Surveys that gather more general consumer information - and that are not framed specifically as an electricity or green tariff survey - could, without potential framing bias, reveal additional information about consumer behaviour.

\section{Methodology}

\subsection{Sample}

The research used cross-sectional data from the Understanding Society Survey (USS), the UK's household longitudinal study, producing annual waves of data from 2009/10 onwards.

Exploration of the USS data holds a number of considerable advantages over existing green tariff studies:

- The sample size is far greater than other existing studies

- The geographical extent of the study is larger than most other studies

- The sheer number of variables available through USS allow for a far broader exploration of potential influences on green tariff adoption

- The sample does not suffer from potential framing bias: USS is a general household study, and is not focussed specifically on green tariff adoption

- USS is conducted annually, so the research can be repeated on a yearly basis to determine longitudinal trends; all other studies have been 'one-offs'?

\subsection{Regression models}

The research was based on a series of probit regressions ${ }^{3}$, using a dependent variable derived from the following USS question:

\section{"Does your household buy, or is your household seriously considering buying its electricity on a Green Tariff?”}

USS respondents were able to choose from four answers to this question:

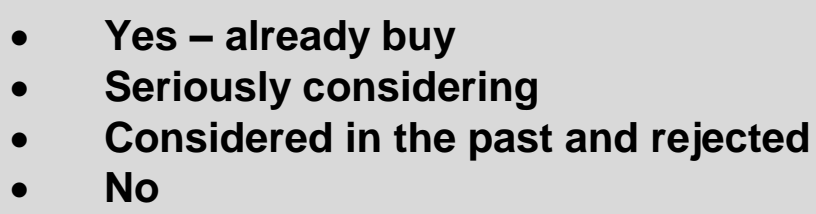

The core model focused squarely on identifying variables characterising those consumers that actually purchase a green tariff, aggregating all other responses into a single response group of consumers that don't purchase a green tariff:

\footnotetext{
${ }^{2}$ Wave II of the USS is scheduled to be released in late 2012

${ }^{3}$ Logit models were also tested, returning similar results to the probit models.
} 

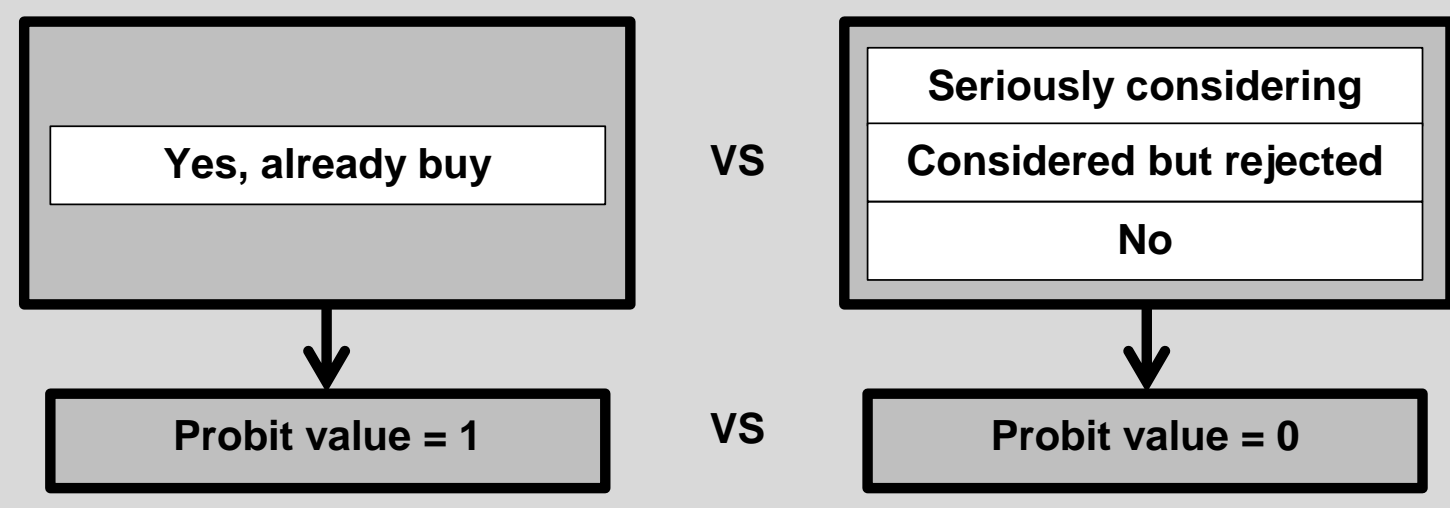

Figure 1: Core model (probit regression)

While the above illustrates the core model, additional regressions were undertaken in order to develop a complete a picture as possible of characteristics defining (and differentiating) each respondent group. Table 1 presents the full set of regressions applied.

Table 1: Regression models and dependent variable probit values

\begin{tabular}{|c|c|c|c|c|}
\hline \multirow{2}{*}{ Model } & \multicolumn{4}{|c|}{ Probit values } \\
\cline { 2 - 5 } & Yes & Considering & Rejected & No \\
\hline A & 1 & 0 & 0 & 0 \\
\hline B & 1 & 0 & $($ removed) & (removed) \\
\hline C & 1 & $($ removed) & 0 & (removed) \\
\hline D & 1 & (removed) & (removed) & 0 \\
\hline
\end{tabular}

Given that all models are binary dependent variable regression results were analysed using the average marginal effects of explanatory variables, rather than slope coefficients.

\subsection{Dependent variable limitation}

The research made use of two USS components - a household-level survey and an individual-level survey. Individual data can easily be mapped to household data and in most instances this is a logical, justified process. To take the clearest example, if the household survey indicates that the house is in Scotland, then it follows that all individuals permanently living in that house also live in Scotland. However, the household survey also contains variables that are less obviously associable to the individual. Of particular relevance to this study is the green tariff question (i.e. the dependent variable), which is collected at the household level. A core assumption of this study is that the household answer to the green tariff question subsequently applies to all adults living within that household. For example, if a household is recorded as 'seriously considering a green tariff', then all adults within that household are assumed to be 'seriously considering a green tariff'. This is clearly 
imperfect, so it is important to be cognisant of this assumption when interpreting results.

Table 2: Explanatory variables and families ${ }^{4}$

\begin{tabular}{|c|c|c|}
\hline \multicolumn{3}{|c|}{ Family 1: Preferences and behaviours } \\
\hline Variable & Description & Values \\
\hline politics & Political leaning & Nominal (7 political parties) \\
\hline commun & $\begin{array}{l}\text { Community-mindedness: derived } \\
\text { from } 8 \text { USS questions }\end{array}$ & Likert (Cronbach's alpha $=0.88)$ \\
\hline relig & Religious? & Dummy (yes/no) \\
\hline envbvr & $\begin{array}{l}\text { Environmental behaviour: derived } \\
\text { from } 10 \text { USS questions }\end{array}$ & Likert (Cronbach's alpha $=0.57$ ) \\
\hline envatt & $\begin{array}{l}\text { Environmental attitude: derived from } \\
8 \text { USS questions }\end{array}$ & $($ Cronbach's Alpha $=0.61)$ \\
\hline renewgen & $\begin{array}{l}\text { House has solar for electricity } \\
\text { AND/OR solar for water } \\
\text { AND/OR wind for electricity? }\end{array}$ & Dummy (yes/no) \\
\hline \multicolumn{3}{|c|}{ Family 2: Demographic variables } \\
\hline sex & Sex & Dummy (female/male) \\
\hline dvage & Age & Interval \\
\hline wfp & Receive winter fuel payment & Dummy (yes/no) \\
\hline hiqual & Highest qualification & Ordinal (4 categories) \\
\hline hhtype & Children in household? & Dummy (yes/no) \\
\hline hhincyr & Annual household net income & 4 quartiles \\
\hline xpelecy & Annual electricity expenditure & Interval \\
\hline tenure & Housing tenure type & Dummy (owned/rented) \\
\hline employ & Employed? & Dummy (yes/no) \\
\hline gor & Region & Nominal (12 UK regions) \\
\hline
\end{tabular}

\subsection{Explanatory variables}

\footnotetext{
${ }^{4}$ Summary statistics for variables presented in Annex 5
} 
Table 2 presents the full list of the independent variables used in the research, grouped into two 'families', with one containing preference and behaviour variables, the other containing demographic variables ${ }^{5}$.

While most variables are self-explanatory, a number require further exposition. Three variables ('community-mindedness', 'environmental attitudes' and 'environmental behaviour') were derived to aggregate and replace sets of similar USS questions. For example, the USS asks respondents to rank their 'community-mindedness' against a series of eight separate statements, measured on a five-point Likert scale (for example, one such statement is "I borrow things and exchange favours with my neighbours"). Rather than including all eight of these statements, a single 'community-mindedness' variable was constructed using Pevalin \& Robson's (2009) recommended approach. The new 'community-mindedness' variable yielded a Cronbach's Alpha value of 0.88 , suggesting good internal consistency of the new, aggregated variable.

The same approach was applied to develop an 'environmental behaviour' variable from 10 USS statements. Although these statements are explicitly framed to USS respondents as being about their environmental behaviour, they clearly also have an economic dimension (for example, one representative statement is "I car share with others who need to make a similar journey"). Moreover, the variable derived using Pevalin \& Robson's approach returned a comparatively low Cronbach's Alpha of 0.57 . This process was repeated to generate an 'environmental attitude' variable, constructed from 8 USS questions around environmental and climate change attitudes (e.g. one such statement was "I would be prepared to pay more for environmentally-friendly products"). Again, a relatively low Cronbach's Alpha of 0.61 was returned. Given these caveats, any results relating to the environmental behaviour and environmental attitude variables need to be treated with caution.

The household survey also gathered information on whether any renewable energy generation systems were installed. A dummy variable was used to indicate whether a household had solar panels for electricity OR solar panels for water heating OR wind turbines for electricity. Similar to the study's core assumption around the green tariff (section 4.3 above), it has been assumed that if a household has a renewable energy system, all individuals within that household also 'have' a renewable energy system.

For annual household net income, both a linear variable and dummy income quartile variables are used. Quartiles were defined by the data set itself:

- Q1: £0 - £14,796 per annum

- Q2: $£ 14,796-£ 24,202$

- Q3: $£ 24,202-£ 36,927$

- Q4: £36,927 and above

\footnotetext{
${ }^{5}$ Taking the lead from Arkesteijn \& Oerlemans (2005) and Diaz-Rainey \& Ashton (2011), initial regressions were undertaken on the separate variable families, but it was immediately clear that combining all variables together would deliver considerably improved predictive power. For example under the core regression model, family 1 variables returned a pseudo-R2 of 0.069 , family 2 returned a pseudo-R2 of 0.057 , and the combined model returned a pseudo-R2 of 0.133
} 
A variable was also derived to identify households in receipt of the UK's winter fuel payment: any household with at least one individual over the age of 60 by default receives a payment from government of at least $£ 200$.

Dummy variables for the 12 UK geographic regions were also included. Finally, not listed in table 2 is the USS' own weighting variable, which was included in all regressions to adjust for USS selection probabilities, survey non-responses and sampling errors. Annex 2 provides further detail on the original USS questions and data from which all variables were sourced. Summary statistics and Variable correlations are presented in Annex 4 and 5, respectively.

\section{Results}

Prior to considering the regression models and results, table 3 tabulates the basic breakdown of responses to the USS green tariff question:

Table 3: Responses to USS green tariff question

\begin{tabular}{|r|c|}
\hline \multicolumn{2}{|c|}{$\begin{array}{c}\text { Does your household buy, or is your household seriously } \\
\text { considering buying its electricity on a Green Tariff? }\end{array}$} \\
\hline & Sample \\
\hline Yes & $2.57 \%$ \\
\hline Seriously considering & $6.34 \%$ \\
\hline Considered but rejected & $1.85 \%$ \\
\hline No & $89.24 \%$ \\
\hline Total & 8670 \\
\hline
\end{tabular}

The USS data was collected in $2009 / 10$, so uptake has increased considerably since the data quoted in section 2 from Graham (2007), which indicated less than 1\% of households purchased a green tariff. However, the level of uptake indicated by the USS data still represents a tiny proportion of the supposed demand that Graham identifies: there is still an enormous behaviour-intention gap.

\subsection{Core model $(A)$}

The core model (A) - which compared only those respondents that actually bought a green tariff against all other respondents - indicated a number of highly significant variables. Table 4 provides a limited set of results, presenting only those variables identified as statistically significant (full regression results are presented in Annex 5).

Individuals in the highest income quartile, those within the highest qualification category (tertiary education), those supporting the Green political party and those exhibiting strong environmental behaviour were all more likely to have purchased green tariffs. Also highly statistically significant were those households not in receipt of winter fuel payments (i.e. receiving the winter fuel payment meant purchase of a green tariff was less likely). Statistically significant to a lesser degree were those households with some form or renewable energy technology installed (5\% level) and those with strong environmental attitudes (10\% level) - environmental behaviour was therefore a stronger predictor than environmental attitude. Perhaps of equal interest were the variables showing no significance: age, sex, employment status, housing 
tenure (owned or rented), household expenditure on electricity, communitymindedness and religiousness all showed no significance within the core model. Interactions between household income and strong environmental behaviour were also tested, but showed no significance.

\section{Table 4: Model A results}

\begin{tabular}{|c|c|}
\hline \multicolumn{2}{|l|}{$\begin{array}{l}\text { Probit regression } \\
\text { Observations: } 8670\end{array}$} \\
\hline Variable & Marginal Effect (S.E.) \\
\hline \multicolumn{2}{|l|}{ Demographics } \\
\hline Receive winter fuel payment & $-0.014^{\star \star *}(0.005)$ \\
\hline \multicolumn{2}{|c|}{ Qualifications (dummy = grp1: none) } \\
\hline Grp 4: Tertiary & $0.019^{* \star *} \quad(0.007)$ \\
\hline \multicolumn{2}{|l|}{ Income (dummy = Q1) } \\
\hline Quartile 4 & $0.019^{* \star *}(0.006)$ \\
\hline \multicolumn{2}{|c|}{ Political preference (dummy = no party) } \\
\hline Conservative & $0.011^{*}$ \\
\hline Green & $0.047^{* * *}(0.008)$ \\
\hline \multicolumn{2}{|l|}{ Environmental } \\
\hline Env'l behaviour & $0.015^{\star \star \star} \quad(0.003)$ \\
\hline Env'l attitude & $0.014^{*} \quad(0.007)$ \\
\hline Have renewables installed & $0.027^{\star *} \quad(0.010)$ \\
\hline
\end{tabular}

${ }^{*},{ }^{* *},{ }^{* *}$ indicates $10 \%, 5 \%$, and $1 \%$ significance respectively

\subsection{Refining an understanding of adopters (Models B, C \& D)}

Arguably, the results from the core model are the most robust and informative for understanding the 'true' nature of green tariff adopters, as it was the only model that compared actual adopters against all other individuals (i.e. non-adopters). Results from the other models certainly provide a more nuanced understanding of differences between the four respondent groups (i.e. 'yes', 'seriously considering', 'considered but rejected', 'no') but how well defined, for example, are those USS respondents classified as 'seriously considering' purchase of a green tariff? There is no way of ascertaining whether those respondents were actively reviewing the green tariff options available to them, or whether they were - for example - indifferent to (or even unaware of) the product prior to the USS question being posed, at which point they felt they would 'seriously consider' a purchase, but reverted to indifference and inaction once the survey was completed.

Bearing such caveats in mind, the additional regression models are still informative around differences between, to take one example, those individuals that have actually purchased a green tariff and those individuals that are most likely to purchase a green tariff (i.e. those 'seriously considering' a purchase). Table 5 presents limited results for models $B, C$ and $D$, which (as per table 1) compared green tariff adopters to each individual respondent group; results for core model $A$ are also represented for ease of comparison. 
Table 5: Model A-D results

\begin{tabular}{|c|c|c|c|c|}
\hline \multicolumn{5}{|c|}{ Probit regressions } \\
\hline Model: & $\begin{array}{c}A \\
\text { (yes v all) }\end{array}$ & $\begin{array}{c}\text { B } \\
\text { (yes v consider) }\end{array}$ & $\underset{\text { (yes v rejected) }}{\text { C }}$ & $\begin{array}{c}\text { D } \\
\text { (yes v no) }\end{array}$ \\
\hline Observations: & 8670 & 773 & 374 & 7960 \\
\hline Variable & Marg. Eff. (SE) & Marg. Eff. (SE) & Marg. Eff. (SE) & Marg. Eff. (SE) \\
\hline \multicolumn{5}{|l|}{ Demographics } \\
\hline Sex & $-0.004(0.003)$ & $0.011(0.032)$ & $0.038(0.050)$ & $-0.005(0.004)$ \\
\hline Age & $0.000(0.000)$ & $0.002(0.001)$ & $-0.003(0.002)$ & $0.000(0.000)$ \\
\hline Winter fuel & $-0.014^{* * *}(0.005)$ & $-0.060(0.054)$ & $-0.116(0.086)$ & $-0.015^{\star * \star}(0.006)$ \\
\hline Employed & $0.000(0.004)$ & $-0.021(0.040)$ & $0.026(0.060)$ & $0.001(0.005)$ \\
\hline Tenure (owned) & $0.002(0.004)$ & $-0.052(0.043)$ & $-0.056(0.061)$ & $0.003(0.005)$ \\
\hline Kids in household & $-0.006(0.004)$ & $-0.040(0.035)$ & $-0.165^{\star \star \star}(0.053)$ & $-0.006(0.004)$ \\
\hline Electricity expend & $0.000(0.000)$ & $0.000(0.000)$ & $0.000^{\star \star}(0.000)$ & $0.000(0.000)$ \\
\hline \multicolumn{5}{|c|}{ Qualifications (dummy = grp1: none) } \\
\hline Grp2: Other & $0.016(0.010)$ & $0.085(0.102)$ & $0.163(0.142)$ & $0.018(0.011)$ \\
\hline Grp3: Secondary & $0.011(0.007)$ & $-0.007(0.071)$ & $0.137(0.102)$ & $0.013^{*}(0.008)$ \\
\hline Grp4: Tertiary & $0.019^{\star \star \star}(0.007)$ & $0.019(0.071)$ & $0.130(0.104)$ & $0.022^{\star \star \star}(0.007)$ \\
\hline \multicolumn{5}{|c|}{ Income (dummy = Q1) } \\
\hline Quartile 2 & $0.006(0.006)$ & $0.055(0.056)$ & $-0.139(0.098)$ & $0.006(0.006)$ \\
\hline Quartile 3 & $-0.001(0.006)$ & $-0.003(0.057)$ & $-0.202^{\star \star}(0.098)$ & $-0.001(0.007)$ \\
\hline Quartile 4 & $0.019^{\star \star \star}(0.006)$ & $0.148^{\star * \star}(0.053)$ & $-0.018(0.095)$ & $0.021^{* \star \star}(0.006)$ \\
\hline \multicolumn{5}{|c|}{ Political preference (dummy = no party) } \\
\hline Conservative & $0.011^{*}(0.006)$ & $0.070(0.054)$ & $0.034(0.087)$ & $0.011^{*}(0.006)$ \\
\hline Green & $0.047^{\star \star \star}(0.008)$ & $0.194^{\star \star \star}(0.065)$ & $0.149(0.111)$ & $0.056^{* \star \star}(0.008)$ \\
\hline Other party & $-0.001(0.009)$ & $0.015(0.112)$ & $-0.370^{\star \star}(0.170)$ & $-0.001(0.010)$ \\
\hline \multicolumn{5}{|l|}{ Environmental } \\
\hline Strong behaviour & $0.015^{\star * *}(0.003)$ & $-0.014(0.026)$ & $0.009(0.041)$ & $0.019^{* * *}(0.003)$ \\
\hline Strong attitude & $0.014^{*}(0.007)$ & $0.047(0.070)$ & $0.064(0.115)$ & $0.015^{*}(0.008)$ \\
\hline Have renewables & $0.027^{\star \star}(0.010)$ & $0.052(0.085)$ & (omitted) & $0.031^{* \star}(0.012)$ \\
\hline
\end{tabular}

${ }^{*},{ }^{* *},{ }^{* * *}$ indicates $10 \%, 5 \%$, and $1 \%$ significance respectively

Notwithstanding concerns around the validity of the 'seriously considering' category, model $B$ indicates the key differences between green tariff adopters and those individuals that have not yet adopted but are most likely to purchase the product (i.e. the 'seriously considering' respondents): more simply, what are the variables that will push an individual 'over the edge' to adopt green tariffs? Model B suggests only two highly significant variables: adopters are more likely to be within the top income quartile, and are more likely to support the Green party. There is no statistically significant difference in environmental behaviours or attitudes between the two groups.

Model C compared green tariff adopters to those individuals that had considered a green tariff in the past, but had rejected adoption. Some new variables were identified as significant in this model: those rejecting the tariff were more likely to have children in their household and were more likely to vote for a minority political party. Arguably of most interest though was the fact that the dummy variable 
describing whether or not a household had renewable energy technologies installed was omitted from the regression due to collinearity: in other words those 'rejecting' the green tariff had a tendency to install their own renewable energy instead.

Model D compared green tariff adopters with those individuals that had answered a straight 'no' within the USS survey (i.e. they are not considering and have never considered a green tariff). Unsurprisingly, the results for model $D$ were very similar to model A, with both models sharing the same highly significant variables.

A multinomial logit regression was also undertaken, and served to validate the results delivered by models A-D. The full results of the multinomial model - and indeed all the other model results - are available in Annex 5.

\section{Conclusions}

Green electricity tariffs offer one route through which domestic consumers can exhibit support for - and contribute towards - investment in renewable energy technologies. However, there remains a considerable intention-behaviour gap between expressed support for renewable energy technologies and uptake of green tariff electricity products. A 2011 YouGov survey ${ }^{6}$ indicated that, for example, 74\% of the UK public think that government should be looking to use more solar power (56\% for wind power), yet data from the UK's Understanding Society survey demonstrates that less than $3 \%$ of UK households purchase a green tariff. This research aimed to identify whether this minority of green tariff adopters had any significant characteristics that differentiated them from non-adopters.

Using data from the Understanding Society Survey, a series of probit regressions were undertaken to identify whether any variables characterise consumers that purchase green tariff electricity. The core regression model - which compared all adopters against all non-adopters - found that individuals from the dataset's highest income quartile (households earning more than £36,927 net/annum), those with higher levels of educational qualification, those supporting the Green party, those households not in receipt of winter fuel payments, and those exhibiting strong environmental behaviour were all more likely to have purchased green tariffs. On this latter variable, behaviour was a stronger predictor and descriptor than environmental attitudes, with environmental attitude only significant at the $10 \%$ level. A number of variables showed no significance within the core regression model: age, sex, employment status, housing tenure, household expenditure on electricity, community-mindedness and religiousness all showed no significance.

However, it is clear that these findings cannot adequately explain the huge intentionbehaviour gap between adopters and non-adopters. The generalist nature of Understanding Society survey avoids potential framing bias inherent within other green tariff research, but within this strength lies a weakness: a thorough, more direct exploration of motivations for green tariff adoption/non-adoption is not possible with the data set.

\footnotetext{
${ }^{6}$ Available:

http://cdn.yougov.com/cumulus uploads/document/gm4jg0973n/Sunday\%20Times\%20Results\%201 11125\%20Vl\%20and\%20Trackers.pdf [16.05.12]
} 
It is possible that individuals supporting renewable energy development are not aware of green tariffs, or that low uptake is simply explained by inertia. A general lack of trust in energy companies could also be an important determinant (e.g. Macalister \& King, 2011), potentially exacerbated in this specific situation by the controversy that led to the formation of the Green Energy Certification Scheme. In any case, future research should move beyond exploration of general characteristics of UK green tariff adopters, and should attempt to identify more precisely the motivations for green tariff adoption and non-adoption. 


\section{Annex 1: References}

Ajzen, I. \& Fishbein, M. 1980, Understanding Attitudes and Predicting Social Behavior. Englewood Cliffs, NJ: Prentice Hall.

Arkesteijn, K. \& Oerlemans, L. 2005, "The early adoption of green power by Dutch households An empirical exploration of factors influencing the early adoption of green electricity for domestic purposes", Energy Policy, vol. 33, no. 2, pp. 183-196.

Batley, S. et al. 2001, "Citizen versus consumer: challenges in the UK green power market”, Energy Policy, vol. 29, no. 6, pp. 479-487.

BBC, 2008, "Switching to an Effective 'Green' Energy Tariff”, 08 Jul. Available: http://www.bbc.co.uk/bloom/actions/renewabletariff.shtml [15.05.12]

BP PLC, 2012, BP Energy Outlook 2030. Available:

http://www.bp.com/liveassets/bp internet/globalbp/STAGING/global assets/downloa ds/O/2012 2030 energy outlook booklet.pdf [15.04.12]

Carrington, M. et al, 2010, "Why Ethical Consumers Don't Walk Their Talk: Towards a Framework for Understanding the Gap Between the Ethical Purchase Intentions and Actual Buying Behaviour of Ethically Minded Consumers", Journal of Business Ethics, vol. 97, no. 1, pp. 139-158.

DECC, 2011, UK Renewable Energy Roadmap. London: Department of Energy and Climate Change.

Diaz-Rainey, I. \& Ashton, J. 2008, "Stuck between a ROC and a hard place? Barriers to the take up of green energy in the UK", Energy Policy, vol. 36, no. 8, pp. 30533061.

Friends of the Earth, 2005, "Briefing Note: Green Electricity Tariffs". Available: http://www.foe.co.uk/resource/briefing notes/green electricity tariffs.pdf [15.05.12]

Gerpott, T. \& Mahmudova, I. 2010, "Determinants of Price Mark-Up Tolerance for Green Electricity - Lessons for Environmental Marketing Strategies from a Study of Residential Electricity Customers in Germany", Business Strategy and the Environment, vol. 19, no. 5, pp. 304-318.

Graham, V. 2007, Reality or rhetoric? Green tariffs for domestic consumers. London: National Consumer Council.

Green, R. 2011, "Climate change Mitigation from Renewable Energy: Its Contribution and Cost" in The Economics and Politics of Climate Change, eds. Helm, D. and Hepburn, C. Oxford University Press: Oxford, pp. 284-301.

Hansla, A. et al. 2008, "Psychological determinants of attitude towards and willingness to pay for green electricity”, Energy Policy, vol. 36, no. 2, pp. 768-774.

IEA, 2011, World Energy Outlook 2011. Paris: OECD. 
Kollmuss, A. \& Agyeman, J. 2002, "Mind the Gap: Why do people act environmentally and what are the barriers to pro-environmental behavior?", Environmental Education Research, vol. 8, no. 3, pp. 239-260.

Kotchen, M. \& Moore, M. 2007, "Private provision of environmental public goods: Household participation in green-electricity programs", Journal of Environmental Economics and Management, vol. 53, no. 1, pp. 1-16.

Macalister, T. \& King, M. 2011 "EDF admits: public has lost trust in energy companies", The Guardian, 15 Sep. Available:

http://www.guardian.co.uk/business/2011/sep/15/edf-admits-public-has-lost-trust-inenergy-companies [16.05.12]

Mainieri, T. et al. 1997, "Green Buying: The Influence of Environmental Concern on Consumer Behaviour", The Journal of Social Psychology, vol. 137, no. 2, pp. 189204.

Ozaki, R. 2011, “Adopting Sustainable Innovation: What Makes Consumers Sign up to Green Electricity?", Business Strategy and the Environment, vol. 20, no. 1, pp. 117.

Pevalin, D. \& Robson, K. 2009, The Stata Survival Manual. Maidenhead: Open University Press.

Shrum, L. et al. 1995, "Buyer Characteristics of the Green Consumer and Their Implications for Advertising Strategy", Journal of Advertising, vol. 24, no. 2, pp. 71 82.

Stock, J. \& Watson, M. 2012, Introduction to Econometrics: International Edition. $3^{\text {rd }}$ ed. Harlow: Pearson.

Tversky, A. \& Kahneman, D. 1980, "The Framing of Decisions and the Psychology of Choice", Science, vol. 211, no. 4481, pp. 453-458.

Understanding Society, 2011, UK Household Longitudinal Study: Wave 1, 20092010

User Manual. Available:

http://data.understandingsociety.org.uk/files/data/documentation/wave1/User manua I Understanding Society Wave 1.pdf [15.04.12] 


\section{Annex 2: Variables - source USS questions and data}

\begin{tabular}{|l|l|l|}
\hline Variable & USS question & Possible responses \\
\hline \multirow{5}{*}{ Dependent } & $\begin{array}{l}\text { Does your household buy, or is your household } \\
\text { seriously considering buying its electricity on a Green } \\
\text { Tariff? }\end{array}$ & $\begin{array}{l}\text { - Yes - already buy } \\
\text { - Seriously considering } \\
\text { - Considered in the past } \\
\text { and rejected } \\
\text { - No }\end{array}$ \\
\hline
\end{tabular}

\begin{tabular}{|c|c|c|}
\hline politics & $\begin{array}{l}\text { Two distinct respondent groups: } \\
\text { - Do you think of yourself as a supporter of any one } \\
\text { political party? } \\
\text { - If not, If there were to be a general election } \\
\text { tomorrow, which political party do you think you } \\
\text { would be most likely to support? }\end{array}$ & $\begin{array}{l}\text { - Conservatives } \\
\text { - Labour } \\
\text { - Liberal Democrat } \\
\text { - Scottish National Party } \\
\text { - Green Party } \\
\text { - Other } \\
\text { - None }\end{array}$ \\
\hline commun & $\begin{array}{l}\text { Next, here are some statements about } \\
\text { neighbourhoods. Please tick the box that indicates } \\
\text { how strongly you agree or disagree with each } \\
\text { statement: } \\
\text { - I feel like I belong to this neighbourhood } \\
\text { - The friendships and associations I have with other } \\
\text { people in my neighbourhood mean a lot to me } \\
\text { - If I needed advice about something I could go to } \\
\text { someone in my neighbourhood } \\
\text { - I borrow things and exchange favours with my } \\
\text { - I woighbours } \\
\text { - I something to im to remain a resident of this neighbourhood } \\
\text { for a number of years } \\
\text { - I like to think of myself as similar to the people that } \\
\text { live in this neighbourhood } \\
\text { - I regularly stop and talk with people in my } \\
\text { neighbourhood }\end{array}$ & $\begin{array}{l}\text { USS responses: } \\
\text { - Strongly agree } \\
\text { - Agree } \\
\text { - Neither agree/disagree } \\
\text { - Disagree } \\
\text { - Strongly disagree } \\
\\
\text { commun combines all } \\
\text { statements into a single } \\
\text { variable } \\
\text { (Cronbach's Alpha = 0.88) }\end{array}$ \\
\hline relig & $\begin{array}{l}\text { Do you regard yourself as belonging to any particular } \\
\text { religion? }\end{array}$ & Yes/No \\
\hline envatt & $\begin{array}{l}\text { The next questions are about your opinions on the } \\
\text { environment. Please tick whether, on the whole, you } \\
\text { personally believe or do not believe each of the } \\
\text { following statements. } \\
\text { - I don't believe my behaviour and everyday lifestyle } \\
\text { contribute to climate change } \\
\text { - I would be prepared to pay more for } \\
\text { environmentally-friendly products } \\
\text { - Climate change is beyond control - it's too late to } \\
\text { do anything about it } \\
\text { - The effects of climate change are too far in the } \\
\text { future to really worry me } \\
\text { - Any changes I make to help the environment need } \\
\text { to fit in with my lifestyle } \\
\text { - It's not worth me doing things to help the }\end{array}$ & $\begin{array}{l}\text { envatt combines all } \\
\text { statements into a single } \\
\text { variable } \\
\text { (Cronbach's Alpha }=0.61 \text { ) }\end{array}$ \\
\hline
\end{tabular}




\begin{tabular}{|c|c|c|}
\hline & $\begin{array}{l}\text { environment if others don't do the same } \\
\text { - It's not worth Britain trying to combat climate } \\
\text { change, because other countries will just cancel out } \\
\text { what we do } \\
\text { - People in the UK will be affected by climate change } \\
\text { in the next } 30 \text { years }\end{array}$ & \\
\hline envbvr & $\begin{array}{l}\text { Now a few questions about the environment. Please } \\
\text { look at this card and tell me how often you personally } \\
\text { do each of the following things: } \\
\text { - Switch off lights in rooms that aren't being used } \\
\text { - Keep the tap running while you brush your teeth } \\
\text { - Put more clothes on when you feel cold rather than } \\
\text { putting the heating on or turning it up } \\
\text { - Decide not to buy something because you feel it } \\
\text { has too much packaging } \\
\text { - Buy recycled paper products such as toilet paper or } \\
\text { tissues } \\
\text { - Take your own shopping bag when shopping } \\
\text { - Use public transport (e.g. bus, train) rather than } \\
\text { travel by car } \\
\text { - Walk or cycle for short journeys less than } 2 \text { or } 3 \\
\text { - Car share with others who need to make a similar } \\
\text { journey } \\
\text { - Take fewer flights when possible }\end{array}$ & $\begin{array}{l}\text { USS responses: } \\
\text { - Always } \\
\text { - Very often } \\
\text { - Quite often } \\
\text { - Not very often } \\
\text { - Never } \\
\text { envbvr combines all } \\
\text { statements into a single } \\
\text { variable } \\
\text { (Cronbach's Alpha }=0.57 \text { ) }\end{array}$ \\
\hline renewgen & $\begin{array}{l}\text { - Have you installed solar panels for electricity? } \\
\text { - Have you installed solar panels for water heating? } \\
\text { - Have you installed a wind turbine to generate } \\
\text { electricity? }\end{array}$ & $\begin{array}{l}\text { If respondent answered yes } \\
\text { to one or more of these } \\
\text { questions, then renewgen }=1 \text {, } \\
\text { otherwise renewgen }=0\end{array}$ \\
\hline
\end{tabular}

\begin{tabular}{|c|c|c|}
\hline sex & Coded by USS surveyor & Male/Female \\
\hline dvage & Not a specific question: USS derive age post-survey & Interval \\
\hline wfp & $\begin{array}{l}\text { Not a specific question: Dummy variable derived for } \\
\text { all households with anyone over } 60 \text { years of age }\end{array}$ & Yes/No \\
\hline hiqual & $\begin{array}{l}\text { Not a specific question: USS derive highest } \\
\text { qualification post-survey }\end{array}$ & $\begin{array}{l}\text { - Tertiary } \\
\text { - Secondary } \\
\text { - Other (e.g. vocational) } \\
\text { - No qualifications }\end{array}$ \\
\hline hhtype & $\begin{array}{l}\text { Not a specific question: USS derive number of kids in } \\
\text { household post-survey }\end{array}$ & $\begin{array}{l}\text { Kids in household/No kids in } \\
\text { hh }\end{array}$ \\
\hline hhincyr & $\begin{array}{l}\text { Not a specific question: USS derive monthly } \\
\text { household income post-survey }\end{array}$ & Annual $=$ USS value $\times 12$ \\
\hline xpelecy & $\begin{array}{l}\text { In the last year how much has your household spent } \\
\text { on electricity? }\end{array}$ & $\begin{array}{l}\text { Quartiles: } \\
\text { - Q1: } £ 0-£ 14,796 \text { (pa) } \\
\text { - Q2: } 114,796-£ 24,202 \\
\text { - Q3: } £ 24,202-£ 36,927 \\
\text { - Q4: } £ 36,927 \text { and above }\end{array}$ \\
\hline
\end{tabular}




\begin{tabular}{|c|c|c|}
\hline tenure & $\begin{array}{l}\text { Not a specific question: USS derive tenure post- } \\
\text { survey }\end{array}$ & Owned/Rented \\
\hline employ & Are you in paid employment? & Yes/No \\
\hline gor & $\begin{array}{l}\text { Not a specific question: USS derive UK region post- } \\
\text { survey }\end{array}$ & $\begin{array}{l}\text { - North East } \\
\text { - North West } \\
\text { - Yorkshire \& The Humber } \\
\text { - East Midlands } \\
\text { - West Midlands } \\
\text { - East of England } \\
\text { - London } \\
\text { - South East } \\
\text { - South West } \\
\text { - Wales } \\
\text { - Scotland } \\
\text { - Northern Ireland }\end{array}$ \\
\hline
\end{tabular}




\section{Annex 3: Variable summary statistics}

\begin{tabular}{|l|r|r|r|}
\hline Variable & \multicolumn{1}{|c|}{ Obs } & Mean & \multicolumn{1}{|c|}{ S.D. } \\
\hline Green tariff & 8,670 & 0.026 & 0.158 \\
\hline Sex & 8,670 & 0.542 & 0.498 \\
\hline Age & 8,670 & 45.008 & 16.101 \\
\hline Winter fuel payment & 8,670 & 0.251 & 0.433 \\
\hline Qualifications1: None & 1,315 & - & - \\
Qualifications2: Other & 417 & - & - \\
Qualifications3: Secondary & 3,508 & - & - \\
Qualifications4: Tertiary & 3,430 & - & - \\
\hline Employed & 8,670 & 0.651 & 0.477 \\
\hline IncomeQ1: £0 - £14,796 per annum* & 1,597 & - & - \\
IncomeQ2: £14,796 - £24,202* & 2,012 & - & - \\
IncomeQ3: £24,202 - £36,927* & 2,406 & - & - \\
IncomeQ4: £36,927 and above & 2,655 & - & - \\
\hline Housing tenure & 8,670 & 0.711 & 0.453 \\
\hline Household with kids & 8,670 & 0.389 & 0.488 \\
\hline Electricity expenditure & 8,670 & 621.738 & 405.526 \\
\hline Politics: Conservative & 2,260 & - & - \\
Politics: Labour & 2,562 & - & - \\
Politics: Lib Dem & 912 & - & - \\
Politics: SNP & 118 & - & - \\
Politics: Green & 267 & - & - \\
Politics: Other & 698 & - & - \\
Politics: None & 1,853 & - & - \\
\hline Community-mindedness & 8,670 & 3.599 & 0.751 \\
\hline Religiousness & 8,670 & 0.531 & 0.499 \\
\hline Environmental behaviour & 8,670 & 2.781 & 0.612 \\
\hline Environmental attitude & 8,670 & 0.646 & 0.250 \\
\hline Renewables installed & 8,670 & 0.010 & 0.102 \\
\hline
\end{tabular}

*Income quartiles defined against whole USS sample, rather than sub-set of observations used for core regression model 


\section{Annex 4: Variable correlations}

\begin{tabular}{|c|c|c|c|c|c|c|c|c|c|c|c|c|c|c|c|c|}
\hline 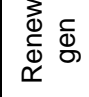 & & & & & & & & & & & & & & & & - \\
\hline 常老 & & & & & & & & & & & & & & & - & ల్ల \\
\hline 岦 & & & & & & & & & & & & & & - & 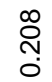 & $\begin{array}{l}0 \\
0 \\
0 \\
0\end{array}$ \\
\hline 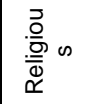 & & & & & & & & & & & & & - & $\stackrel{m}{\circ}$ & סे & $\begin{array}{l}\text { o } \\
\text { ¿ }\end{array}$ \\
\hline 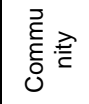 & & & & & & & & & & & & - & $\frac{O}{\frac{9}{0}}$ & : & 总 & $\begin{array}{l}\bar{\sigma} \\
\dot{0}\end{array}$ \\
\hline 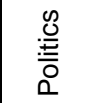 & & & & & & & & & & & - & \begin{tabular}{l}
0 \\
\multirow{0}{0}{} \\
o
\end{tabular} & $\begin{array}{l}\infty \\
0 \\
0 \\
i\end{array}$ & $\begin{array}{l}\infty \\
\infty \\
0 \\
i\end{array}$ & $\begin{array}{l}\stackrel{8}{0} \\
\stackrel{0}{0} \\
0\end{array}$ & $\begin{array}{l}\infty \\
\stackrel{0}{0}\end{array}$ \\
\hline 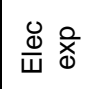 & & & & & & & & & & - & $\stackrel{+}{\circ}$ & $\begin{array}{l}\text { 옹 } \\
0\end{array}$ & $\begin{array}{l}\mathscr{0} \\
\mathscr{O} \\
0\end{array}$ & $\frac{⿱}{\stackrel{0}{0}}$ & $\begin{array}{l}\circ \\
\text { ò } \\
\text { i. }\end{array}$ & $\begin{array}{l}m \\
\\
\end{array}$ \\
\hline$\frac{ \pm}{1} \frac{\frac{0}{0}}{\frac{8}{3}}$ & & & & & & & & & - & 六 & : & $\stackrel{\infty}{0}$ & $\begin{array}{l}\frac{m}{0} \\
\text { i. } \\
\end{array}$ & 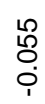 & آم. & $\begin{array}{l}\text { ָे } \\
\text { i. }\end{array}$ \\
\hline 禀 & & & & & & & & $r$ & $\begin{array}{l}0 \\
0 \\
0 \\
0\end{array}$ & $\frac{\text { ô. }}{\circ}$ & $\frac{\overline{5}}{0}$ & $\begin{array}{l}\bar{\sigma} \\
\stackrel{0}{0}\end{array}$ & $\begin{array}{l}\mathscr{L} \\
\stackrel{0}{0} \\
0\end{array}$ & $\begin{array}{l}\hat{\hat{O}} \\
\dot{i}\end{array}$ & 号 & 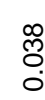 \\
\hline $\begin{array}{l}\stackrel{0}{\Xi} \\
\underline{\underline{0}} \\
\underline{\underline{c}}\end{array}$ & & & & & & & $r$ & $\stackrel{\stackrel{\leftrightarrow}{\leftrightarrow}}{0}$ & $\frac{\text { n) }}{\frac{1}{0}}$ & $\stackrel{\infty}{\frac{\infty}{0}}$ & $\begin{array}{l}\text { o. } \\
0 \\
0 \\
i\end{array}$ & $\begin{array}{l}8 \\
\text { ०े. } \\
\text { i. }\end{array}$ & $\begin{array}{l}\text { §ै } \\
\text { ¿े. }\end{array}$ & $\begin{array}{l}\hat{0} \\
\dot{0}\end{array}$ & 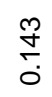 & ָ̃ \\
\hline 亭 $\bar{\Xi}$ & & & & & & $r$ & ్ָల్ల & $\frac{F}{0}$ & $\begin{array}{l}\text { Бे } \\
\text { 잉 }\end{array}$ & $\stackrel{\infty}{\circ}$ & $\begin{array}{l}\widetilde{N} \\
\text { Oे } \\
0\end{array}$ & $\begin{array}{l}\hat{0} \\
\text { o. } \\
\text { i }\end{array}$ & $\begin{array}{l}\text { : } \\
\text { : } \\
\text { i. }\end{array}$ & $\begin{array}{l}0 \\
0 \\
0 \\
1\end{array}$ & $\begin{array}{l}\text { ஜ } \\
\text { Oे }\end{array}$ & $\begin{array}{l}\circ \\
0 \\
0 \\
\end{array}$ \\
\hline$\overline{\widetilde{\sigma}}$ & & & & & - & 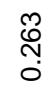 & 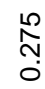 & $\frac{\infty}{\circ}$ & $\begin{array}{l}\mathscr{8} \\
0 \\
0\end{array}$ & $\begin{array}{l}\text { 옹 } \\
0\end{array}$ & م. & $\begin{array}{l}\frac{2}{2} \\
0 \\
0 \\
i\end{array}$ & $\begin{array}{l}\infty \\
0 \\
0 \\
i\end{array}$ & oे & $\begin{array}{l}0 \\
\stackrel{0}{0} \\
0\end{array}$ & $\begin{array}{l}\text { Oे } \\
\text { Oे }\end{array}$ \\
\hline$\frac{0}{3}$ & & & & $\tau$ & $\begin{array}{l}\stackrel{0}{N} \\
\stackrel{N}{i} \\
\stackrel{i}{1}\end{array}$ & 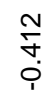 & $\frac{\stackrel{+}{S}}{\stackrel{i}{i}}$ & $\frac{\bar{\sigma}}{0}$ & 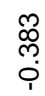 & $\begin{array}{l}\hat{\phi} \\
\text { i. }\end{array}$ & $\frac{\stackrel{q}{m}}{\stackrel{p}{i}}$ & $\stackrel{\infty}{\stackrel{2}{0}}$ & 息 & $\begin{array}{l}\text { ֻू } \\
\text { O. } \\
0\end{array}$ & $\begin{array}{l}\overline{1} \\
0 \\
0 \\
0\end{array}$ & $\underset{\text { Jै }}{\stackrel{y}{0}}$ \\
\hline$\stackrel{8}{8}$ & & & - & $\begin{array}{l}0 \\
0 \\
0 \\
0\end{array}$ & $\begin{array}{l}\hat{N} \\
\stackrel{N}{0} \\
\stackrel{i}{i}\end{array}$ & 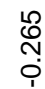 & $\frac{m}{\stackrel{m}{\circ}}$ & 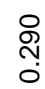 & 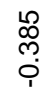 & $\begin{array}{l}8 \\
0 \\
\text { i. }\end{array}$ & $\frac{\infty}{\frac{\infty}{.0}}$ & $\begin{array}{l}\stackrel{+}{0} \\
\stackrel{0}{0}\end{array}$ & $\frac{0}{\frac{0}{0}}$ & $\begin{array}{l}\mathscr{0} \\
\mathscr{O} \\
0\end{array}$ & $\begin{array}{l}\hat{0} \\
0 \\
0\end{array}$ & ஜֶ̊ \\
\hline$\stackrel{\times}{\infty}$ & & $\tau$ & $\begin{array}{l}\overline{8} \\
0 \\
i\end{array}$ & $\begin{array}{l}\stackrel{L}{0} \\
\text { O̊. } \\
\text { i }\end{array}$ & 伞 & $\begin{array}{l}\infty \\
\mathscr{0} \\
0 \\
\text { i. }\end{array}$ & $\begin{array}{l}\qquad 0 \\
\varnothing \\
0 \\
\end{array}$ & 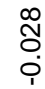 & $\begin{array}{l}0 \\
0 \\
0\end{array}$ & $\begin{array}{l}8 \\
\text { ¿ } \\
\text { i. }\end{array}$ & \begin{tabular}{l}
0 \\
\multirow{0}{0}{} \\
0
\end{tabular} & $\begin{array}{l}\bar{\sigma} \\
0\end{array}$ & 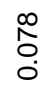 & $\frac{8}{0}$ & $\begin{array}{l}\text { 号 } \\
0\end{array}$ & $\begin{array}{l}0 \\
\vdots \\
0 \\
0\end{array}$ \\
\hline 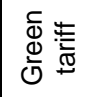 & - & $\begin{array}{l}\text { oे } \\
\text { i }\end{array}$ & 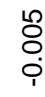 & $\begin{array}{l}\text { o. } \\
0 \\
\text { o. } \\
i\end{array}$ & $\begin{array}{l}\hat{\theta} \\
0\end{array}$ & ్ֶల్ & \&్ & $\begin{array}{l}\text { Ñ } \\
\text { Oे }\end{array}$ & $\begin{array}{l}\frac{m}{0} \\
\text { i. }\end{array}$ & $\begin{array}{l}\overline{8} \\
\text { ㅇ․ }\end{array}$ & $\begin{array}{l}\hat{N} \\
\text { Oे. } \\
\text { i. }\end{array}$ & $\begin{array}{l}\circ \\
0 \\
0\end{array}$ & $\begin{array}{l}\text { đ̃ } \\
0 \\
0\end{array}$ & $\begin{array}{l}\mathscr{2} \\
\stackrel{0}{0} \\
0\end{array}$ & $\begin{array}{l}\ddot{8} \\
\ddot{0} \\
0\end{array}$ & 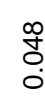 \\
\hline & 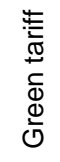 & $\widehat{\oplus}$ & g & 足 & व̃ & 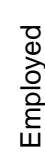 & $\begin{array}{l}\stackrel{0}{0} \\
\text { 토 }\end{array}$ & 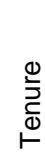 & 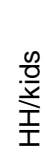 & $\begin{array}{l}\vec{x} \\
0 \\
\mathbb{\Phi}\end{array}$ & $\begin{array}{l}\frac{0}{3} \\
\frac{\underline{t}}{0} \\
0\end{array}$ & 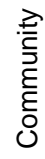 & 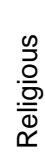 & 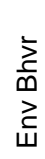 & 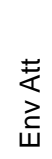 & 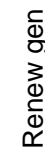 \\
\hline
\end{tabular}




\section{Annex 5: Full regression results}

\begin{tabular}{|c|c|c|c|c|c|c|c|}
\hline \multicolumn{8}{|c|}{$\begin{array}{l}\text { MODEL A } \\
\text { Dependent }=\text { Yes }(\text { vs Considering }+ \text { Rejected }+ \text { No })\end{array}$} \\
\hline \multicolumn{5}{|c|}{ Probit regression } & \multicolumn{2}{|c|}{$\begin{array}{l}\text { Number of obs } \\
\text { Wald chi2(36) }\end{array}$} & \multirow{3}{*}{$\begin{array}{l}8670 \\
227.23 \\
0.0000 \\
0.1186\end{array}$} \\
\hline Log likelihood & & & & & Prob > ch & & \\
\hline-913.4353 & & & & & Pseudo $\mathrm{P}$ & & \\
\hline variable & 1 & $d y / d x$ & $\begin{array}{l}\text { Unconditional } \\
\text { Std. Err. }\end{array}$ & z & $P>|z|$ & [ 95\% & C.I. ] \\
\hline -------- & + & ----------- & ------------- & ------- & ----- & L ---------- & \begin{tabular}{|c|}
-------- \\
$-\cdot-$
\end{tabular} \\
\hline Sex & & -0.004 & 0.003 & -1.040 & $\begin{array}{l}0.296 \\
\end{array}$ & -0.010 & 0.003 \\
\hline Age & & 0.000 & 0.000 & 1.100 & 0.272 & 0.000 & 0.000 \\
\hline Winter fuel & & -0.014 & 0.005 & -2.650 & 0.008 & -0.024 & -0.004 \\
\hline Qualific2 & & 0.016 & 0.010 & 1.530 & 0.125 & -0.004 & 0.036 \\
\hline Qualific3 & & 0.011 & 0.007 & 1.610 & 0.108 & -0.003 & 0.025 \\
\hline Qualific4 & & 0.019 & 0.007 & 2.740 & 0.006 & 0.005 & 0.033 \\
\hline Employed & & 0.000 & 0.004 & 0.110 & 0.912 & -0.008 & 0.009 \\
\hline IncomeQ2 & & 0.006 & 0.006 & 0.950 & 0.343 & -0.006 & 0.017 \\
\hline IncomeQ3 & & -0.001 & 0.006 & -0.220 & 0.829 & -0.013 & 0.011 \\
\hline IncomeQ4 & & 0.019 & 0.006 & 3.310 & 0.001 & 0.008 & 0.031 \\
\hline Tenure & & 0.002 & 0.004 & 0.430 & 0.670 & -0.007 & 0.010 \\
\hline Kids in house & & -0.006 & 0.004 & -1.560 & 0.119 & -0.013 & 0.001 \\
\hline Elec expend & & 0.000 & 0.000 & 0.710 & 0.476 & 0.000 & 0.000 \\
\hline North East & & 0.013 & 0.008 & 1.580 & 0.114 & -0.003 & 0.029 \\
\hline North West & & 0.002 & 0.005 & 0.310 & 0.756 & -0.008 & 0.012 \\
\hline Yorks Humb & & -0.014 & 0.008 & -1.760 & 0.078 & -0.030 & 0.002 \\
\hline E Midlands & & 0.019 & 0.005 & 3.420 & 0.001 & 0.008 & 0.030 \\
\hline W Midlands & & -0.014 & 0.008 & -1.790 & 0.074 & -0.030 & 0.001 \\
\hline E England & & 0.010 & 0.005 & 2.120 & 0.034 & 0.001 & 0.019 \\
\hline London & & 0.001 & 0.004 & 0.200 & 0.843 & -0.007 & 0.009 \\
\hline South East & & 0.011 & 0.004 & 2.750 & 0.006 & 0.003 & 0.018 \\
\hline South West & & -0.005 & 0.006 & -0.880 & 0.377 & -0.017 & 0.006 \\
\hline Wales & & -0.011 & 0.009 & -1.200 & 0.231 & -0.028 & 0.007 \\
\hline Scotland & & -0.001 & 0.007 & -0.110 & 0.916 & -0.014 & 0.013 \\
\hline $\mathrm{N}$ Ireland & & -0.010 & 0.009 & -1.140 & 0.255 & -0.027 & 0.007 \\
\hline Tories & & 0.011 & 0.006 & 1.960 & 0.050 & 0.000 & 0.022 \\
\hline Labour & & 0.007 & 0.005 & 1.350 & 0.176 & -0.003 & 0.018 \\
\hline Lib Dem & & 0.006 & 0.007 & 0.960 & 0.337 & -0.007 & 0.020 \\
\hline SNP & & 0.014 & 0.016 & 0.870 & 0.382 & -0.017 & 0.044 \\
\hline Green & & 0.047 & 0.008 & 6.260 & 0.000 & 0.032 & 0.062 \\
\hline Other party & & -0.001 & 0.009 & -0.150 & 0.883 & -0.020 & 0.017 \\
\hline Community & & 0.001 & 0.002 & 0.520 & 0.606 & -0.004 & 0.006 \\
\hline Religious & & -0.005 & 0.003 & -1.360 & 0.175 & -0.011 & 0.002 \\
\hline Env Behav & & 0.015 & 0.003 & 4.940 & 0.000 & 0.009 & 0.021 \\
\hline Env Attitude & & 0.014 & 0.007 & 1.900 & 0.058 & 0.000 & 0.028 \\
\hline Renewables & & 0.027 & 0.010 & 2.590 & 0.010 & 0.007 & 0.047 \\
\hline
\end{tabular}




\begin{tabular}{|c|c|c|c|c|c|c|c|}
\hline \multicolumn{8}{|c|}{$\begin{array}{l}\text { MODEL B } \\
\text { Dependent = Yes (vs Considering; Rejected and No removed) }\end{array}$} \\
\hline \multicolumn{5}{|c|}{ Probit regression } & \multicolumn{2}{|c|}{$\begin{array}{l}\text { Number of obs } \\
\text { Wald chi2(36) }\end{array}$} & \multirow{3}{*}{$\begin{array}{l}773 \\
84.06 \\
0.0000 \\
0.0984\end{array}$} \\
\hline Log likelihood & & & & & Prob $>\mathrm{cr}$ & & \\
\hline-418.73458 & & & & & Pseudo F & & \\
\hline variable & 1 & $d y / d x$ & $\begin{array}{l}\text { Unconditional } \\
\text { Std. Err. }\end{array}$ & z & $\mathrm{P}>|\mathrm{z}|$ & [ 95\% & C.I. ] \\
\hline - ------- & + & ------------ & -------------- & -------- & ------- & |---------- & ---------- \\
\hline Sex & & 0.011 & 0.032 & 0.330 & 0.739 & -0.053 & 0.074 \\
\hline Age & & 0.002 & 0.001 & 1.160 & 0.245 & -0.001 & 0.005 \\
\hline Winter fuel & & -0.060 & 0.054 & -1.120 & 0.262 & -0.166 & 0.045 \\
\hline Qualific2 & & 0.085 & 0.102 & 0.830 & 0.406 & -0.115 & 0.285 \\
\hline Qualific3 & & -0.007 & 0.071 & -0.100 & 0.923 & -0.146 & 0.132 \\
\hline Qualific4 & & 0.019 & 0.071 & 0.270 & 0.791 & -0.120 & 0.157 \\
\hline Employed & & -0.021 & 0.040 & -0.520 & 0.601 & -0.099 & 0.058 \\
\hline IncomeQ2 & & 0.055 & 0.056 & 0.980 & 0.327 & -0.055 & 0.165 \\
\hline IncomeQ3 & & -0.003 & 0.057 & -0.050 & 0.959 & -0.115 & 0.109 \\
\hline IncomeQ4 & & 0.148 & 0.053 & 2.780 & 0.005 & 0.044 & 0.252 \\
\hline Tenure & & -0.052 & 0.043 & -1.210 & 0.227 & -0.137 & 0.033 \\
\hline Kids in house & & -0.040 & 0.035 & -1.160 & 0.244 & -0.108 & 0.028 \\
\hline Elec expend & & 0.000 & 0.000 & -1.550 & 0.121 & 0.000 & 0.000 \\
\hline North East & & 0.174 & 0.085 & 2.060 & 0.040 & 0.008 & 0.341 \\
\hline North West & & 0.035 & 0.049 & 0.720 & 0.470 & -0.060 & 0.131 \\
\hline Yorks Humb & & -0.210 & 0.064 & -3.290 & 0.001 & -0.336 & -0.085 \\
\hline E Midlands & & 0.047 & 0.051 & 0.920 & 0.357 & -0.053 & 0.148 \\
\hline W Midlands & & -0.088 & 0.076 & -1.160 & 0.247 & -0.236 & 0.061 \\
\hline E England & & 0.072 & 0.047 & 1.550 & 0.122 & -0.019 & 0.163 \\
\hline London & & -0.007 & 0.039 & -0.180 & 0.857 & -0.084 & 0.070 \\
\hline South East & & 0.120 & 0.040 & 2.990 & 0.003 & 0.041 & 0.200 \\
\hline South West & & 0.021 & 0.057 & 0.360 & 0.718 & -0.091 & 0.132 \\
\hline Wales & & -0.067 & 0.083 & -0.810 & 0.419 & -0.229 & 0.096 \\
\hline Scotland & & 0.008 & 0.066 & 0.120 & 0.904 & -0.121 & 0.137 \\
\hline $\mathrm{N}$ Ireland & & -0.106 & 0.097 & -1.090 & 0.277 & -0.297 & 0.085 \\
\hline Tories & & 0.070 & 0.054 & 1.300 & 0.195 & -0.036 & 0.176 \\
\hline Labour & & 0.028 & 0.052 & 0.530 & 0.598 & -0.075 & 0.130 \\
\hline Lib Dem & & -0.002 & 0.064 & -0.030 & 0.979 & -0.127 & 0.123 \\
\hline SNP & & 0.051 & 0.144 & 0.350 & 0.724 & -0.231 & 0.332 \\
\hline Green & & 0.194 & 0.065 & 2.990 & 0.003 & 0.067 & 0.320 \\
\hline Other party & & 0.015 & 0.112 & 0.130 & 0.895 & -0.205 & 0.235 \\
\hline Community & & 0.007 & 0.024 & 0.290 & 0.775 & -0.041 & 0.055 \\
\hline Religious & & -0.028 & 0.033 & -0.860 & 0.392 & -0.092 & 0.036 \\
\hline Env Behav & & -0.014 & 0.026 & -0.560 & 0.576 & -0.065 & 0.036 \\
\hline Env Attitude & & 0.047 & 0.070 & 0.660 & 0.507 & -0.091 & 0.185 \\
\hline Renewables & & 0.052 & 0.085 & 0.610 & 0.542 & -0.115 & 0.218 \\
\hline
\end{tabular}


MODEL C

Dependent $=$ Yes (vs Rejected; Considering and No removed)

Probit regression

Number of obs

374

Log likelihood

Wald chi2(35)

78.18

Prob $>$ chi2

0.0000

$-213.24296$

Pseudo R2

0.1648

\begin{tabular}{|c|c|c|c|c|c|c|c|}
\hline \\
\hline variable & I & $d y / d x$ & $\begin{array}{l}\text { Unconditional } \\
\text { Std. Err. }\end{array}$ & z & $\mathrm{P}>|\mathrm{z}|$ & [ $95 \%$ & C.I. ] \\
\hline --------- & + & ----------- & -------------- & -------- & ------- & ---------- & ---------- \\
\hline Sex & & 0.038 & 0.050 & 0.780 & 0.438 & -0.059 & 0.136 \\
\hline Age & & -0.003 & 0.002 & -1.220 & 0.221 & -0.007 & 0.002 \\
\hline Winter fuel & & -0.116 & 0.086 & -1.350 & 0.178 & -0.286 & 0.053 \\
\hline Qualific2 & & 0.163 & 0.142 & 1.150 & 0.251 & -0.115 & 0.441 \\
\hline Qualific3 & & 0.137 & 0.102 & 1.340 & 0.182 & -0.064 & 0.337 \\
\hline Qualific4 & & 0.130 & 0.104 & 1.250 & 0.211 & -0.073 & 0.333 \\
\hline Employed & & 0.026 & 0.060 & 0.440 & 0.657 & -0.090 & 0.143 \\
\hline IncomeQ2 & & -0.139 & 0.098 & -1.420 & 0.156 & -0.331 & 0.053 \\
\hline IncomeQ3 & & -0.202 & 0.098 & -2.070 & 0.039 & -0.394 & -0.010 \\
\hline IncomeQ4 & & -0.018 & 0.095 & -0.190 & 0.847 & -0.205 & 0.168 \\
\hline Tenure & & -0.056 & 0.061 & -0.920 & 0.360 & -0.176 & 0.064 \\
\hline Kids in house & & -0.165 & 0.053 & -3.100 & 0.002 & -0.269 & -0.060 \\
\hline Elec expend & & 0.000 & 0.000 & 2.010 & 0.045 & 0.000 & 0.000 \\
\hline North East & & 0.145 & 0.187 & 0.780 & 0.437 & -0.221 & 0.511 \\
\hline North West & & -0.049 & 0.077 & -0.640 & 0.524 & -0.199 & 0.101 \\
\hline Yorks Humb & & -0.125 & 0.107 & -1.170 & 0.242 & -0.336 & 0.085 \\
\hline E Midlands & & 0.080 & 0.082 & 0.980 & 0.328 & -0.080 & 0.240 \\
\hline W Midlands & & -0.024 & 0.102 & -0.230 & 0.817 & -0.223 & 0.176 \\
\hline E England & & -0.093 & 0.071 & -1.320 & 0.186 & -0.232 & 0.045 \\
\hline London & & 0.146 & 0.063 & 2.320 & 0.020 & 0.023 & 0.269 \\
\hline South East & & 0.060 & 0.059 & 1.020 & 0.307 & -0.055 & 0.174 \\
\hline South West & & -0.213 & 0.076 & -2.790 & 0.005 & -0.362 & -0.064 \\
\hline Wales & & -0.193 & 0.118 & -1.640 & 0.101 & -0.423 & 0.038 \\
\hline Scotland & & 0.010 & 0.096 & 0.100 & 0.919 & -0.178 & 0.197 \\
\hline $\mathrm{N}$ Ireland & & 0.256 & 0.171 & 1.500 & 0.133 & -0.078 & 0.591 \\
\hline Tories & & 0.034 & 0.087 & 0.390 & 0.693 & -0.137 & 0.206 \\
\hline Labour & & -0.107 & 0.085 & -1.260 & 0.208 & -0.274 & 0.060 \\
\hline Lib Dem & & -0.130 & 0.094 & -1.390 & 0.164 & -0.314 & 0.053 \\
\hline SNP & & 0.111 & 0.236 & 0.470 & 0.639 & -0.352 & 0.573 \\
\hline Green & & 0.149 & 0.111 & 1.350 & 0.178 & -0.068 & 0.366 \\
\hline Other party & & -0.370 & 0.170 & -2.180 & 0.029 & -0.703 & -0.037 \\
\hline Community & & -0.013 & 0.035 & -0.360 & 0.717 & -0.080 & 0.055 \\
\hline Religious & & -0.001 & 0.048 & -0.030 & 0.975 & -0.096 & 0.093 \\
\hline Env Behav & & 0.009 & 0.041 & 0.210 & 0.834 & -0.072 & 0.089 \\
\hline Env Attitude & & 0.064 & 0.115 & 0.560 & 0.574 & -0.160 & 0.289 \\
\hline Renewables & & (omitted) & & & & & \\
\hline
\end{tabular}




\begin{tabular}{|c|c|c|c|c|c|c|c|}
\hline \multicolumn{8}{|c|}{$\begin{array}{l}\text { MODEL D } \\
\text { Dependent = Yes (vs No; Considering and Rejected removed) }\end{array}$} \\
\hline \multicolumn{5}{|c|}{ Probit regression } & \multicolumn{2}{|c|}{$\begin{array}{l}\text { Number of obs } \\
\text { Wald chi2(36) }\end{array}$} & \multirow{3}{*}{$\begin{array}{l}7960 \\
244.83 \\
0.0000 \\
0.1354\end{array}$} \\
\hline Log likelihood & & & & & Prob $>$ ch & & \\
\hline-879.39852 & & & & & Pseudo $\mathrm{R}$ & & \\
\hline variable & & $d y / d x$ & $\begin{array}{l}\text { Unconditional } \\
\text { Std. Err. }\end{array}$ & $z$ & $\mathrm{P}>|\mathrm{z}|$ & [ $95 \%$ & C.I. ] \\
\hline ---------- & + & ------------ & --------------- & -------- & ------- & 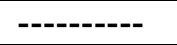 & ----------- \\
\hline Sex & & -0.005 & 0.004 & -1.270 & 0.204 & -0.012 & 0.003 \\
\hline Age & & 0.000 & 0.000 & 1.130 & 0.259 & 0.000 & 0.001 \\
\hline Winter fuel & & -0.015 & 0.006 & -2.640 & 0.008 & -0.026 & -0.004 \\
\hline Qualific2 & & 0.018 & 0.011 & 1.610 & 0.107 & -0.004 & 0.039 \\
\hline Qualific3 & & 0.013 & 0.008 & 1.730 & 0.084 & -0.002 & 0.028 \\
\hline Qualific4 & & 0.022 & 0.007 & 2.970 & 0.003 & 0.008 & 0.037 \\
\hline Employed & & 0.001 & 0.005 & 0.320 & 0.748 & -0.007 & 0.010 \\
\hline IncomeQ2 & & 0.006 & 0.006 & 0.940 & 0.349 & -0.006 & 0.018 \\
\hline IncomeQ3 & & -0.001 & 0.007 & -0.180 & 0.858 & -0.014 & 0.012 \\
\hline IncomeQ4 & & 0.021 & 0.006 & 3.300 & 0.001 & 0.008 & 0.033 \\
\hline Tenure & & 0.003 & 0.005 & 0.700 & 0.485 & -0.006 & 0.013 \\
\hline Kids in house & & -0.006 & 0.004 & -1.570 & 0.115 & -0.014 & 0.002 \\
\hline Elec expend & & 0.000 & 0.000 & 1.070 & 0.284 & 0.000 & 0.000 \\
\hline North East & & 0.015 & 0.009 & 1.750 & 0.079 & -0.002 & 0.032 \\
\hline North West & & 0.001 & 0.006 & 0.210 & 0.834 & -0.010 & 0.012 \\
\hline Yorks Humb & & -0.013 & 0.009 & -1.480 & 0.139 & -0.030 & 0.004 \\
\hline E Midlands & & 0.022 & 0.006 & 3.700 & 0.000 & 0.010 & 0.034 \\
\hline W Midlands & & -0.017 & 0.009 & -1.920 & 0.054 & -0.033 & 0.000 \\
\hline E England & & 0.011 & 0.005 & 2.180 & 0.029 & 0.001 & 0.021 \\
\hline London & & 0.001 & 0.005 & 0.160 & 0.872 & -0.008 & 0.010 \\
\hline South East & & 0.011 & 0.004 & 2.590 & 0.010 & 0.003 & 0.019 \\
\hline South West & & -0.007 & 0.006 & -1.040 & 0.299 & -0.019 & 0.006 \\
\hline Wales & & -0.012 & 0.009 & -1.290 & 0.198 & -0.031 & 0.006 \\
\hline Scotland & & -0.001 & 0.007 & -0.100 & 0.924 & -0.015 & 0.014 \\
\hline $\mathrm{N}$ Ireland & & -0.012 & 0.009 & -1.280 & 0.202 & -0.030 & 0.006 \\
\hline Tories & & 0.011 & 0.006 & 1.890 & 0.059 & 0.000 & 0.023 \\
\hline Labour & & 0.009 & 0.006 & 1.450 & 0.146 & -0.003 & 0.020 \\
\hline Lib Dem & & 0.008 & 0.007 & 1.150 & 0.250 & -0.006 & 0.023 \\
\hline SNP & & 0.015 & 0.017 & 0.890 & 0.374 & -0.018 & 0.048 \\
\hline Green & & 0.056 & 0.008 & 6.840 & 0.000 & 0.040 & 0.072 \\
\hline Other party & & -0.001 & 0.010 & -0.070 & 0.945 & -0.020 & 0.019 \\
\hline Community & & 0.002 & 0.003 & 0.690 & 0.492 & -0.003 & 0.007 \\
\hline Religious & & -0.006 & 0.004 & -1.530 & 0.125 & -0.013 & 0.002 \\
\hline Env Behav & & 0.019 & 0.003 & 5.560 & 0.000 & 0.012 & 0.025 \\
\hline Env Attitude & & 0.015 & 0.008 & 1.890 & 0.059 & -0.001 & 0.030 \\
\hline Renewables & & 0.031 & 0.012 & 2.650 & 0.008 & 0.008 & 0.053 \\
\hline
\end{tabular}




\begin{tabular}{|c|c|c|c|c|c|c|c|}
\hline \multicolumn{8}{|c|}{$\begin{array}{l}\text { MULTINOMIAL LOGIT } \\
\text { YES }\end{array}$} \\
\hline \multicolumn{5}{|c|}{ Logistic regression } & \multicolumn{2}{|c|}{$\begin{array}{l}\text { Number of obs } \\
\text { Wald chi2(108) }\end{array}$} & \multirow{3}{*}{$\begin{array}{l}8670 \\
9356.55 \\
0.0000 \\
0.1008\end{array}$} \\
\hline Log likelihood & & & & & Prob $>$ ch & & \\
\hline-3464.3872 & & & & & Pseudo R & & \\
\hline variable & & $d y / d x$ & $\begin{array}{l}\text { Unconditional } \\
\text { Std. Err. }\end{array}$ & $z$ & $P>|z|$ & [ 95\% & C.I. ] \\
\hline --------- & + & ------------ & --------------- & -------- & ------- & |---------- & ----------- \\
\hline Sex & & -0.004 & 0.004 & -1.210 & 0.224 & -0.011 & 0.003 \\
\hline Age & & 0.000 & 0.000 & 1.090 & 0.276 & 0.000 & 0.001 \\
\hline Winter fuel & & -0.014 & 0.006 & -2.590 & 0.010 & -0.025 & -0.003 \\
\hline Qualific2 & & 0.015 & 0.012 & 1.320 & 0.186 & -0.007 & 0.038 \\
\hline Qualific3 & & 0.013 & 0.008 & 1.600 & 0.109 & -0.003 & 0.029 \\
\hline Qualific4 & & 0.020 & 0.008 & 2.550 & 0.011 & 0.005 & 0.036 \\
\hline Employed & & 0.000 & 0.004 & 0.010 & 0.993 & -0.009 & 0.009 \\
\hline IncomeQ2 & & 0.007 & 0.006 & 1.170 & 0.244 & -0.005 & 0.020 \\
\hline IncomeQ3 & & -0.002 & 0.007 & -0.270 & 0.788 & -0.015 & 0.011 \\
\hline IncomeQ4 & & 0.020 & 0.006 & 3.170 & 0.002 & 0.008 & 0.032 \\
\hline Tenure & & 0.003 & 0.005 & 0.630 & 0.530 & -0.006 & 0.012 \\
\hline Kids in house & & -0.005 & 0.004 & -1.320 & 0.187 & -0.013 & 0.002 \\
\hline Elec expend & & 0.000 & 0.000 & 0.470 & 0.640 & 0.000 & 0.000 \\
\hline North East & & 0.013 & 0.008 & 1.550 & 0.122 & -0.004 & 0.030 \\
\hline North West & & 0.002 & 0.005 & 0.320 & 0.748 & -0.009 & 0.012 \\
\hline Yorks Humb & & -0.013 & 0.009 & -1.460 & 0.143 & -0.029 & 0.004 \\
\hline E Midlands & & 0.018 & 0.005 & 3.300 & 0.001 & 0.007 & 0.028 \\
\hline W Midlands & & -0.015 & 0.009 & -1.580 & 0.113 & -0.033 & 0.003 \\
\hline E England & & 0.011 & 0.005 & 2.270 & 0.023 & 0.002 & 0.020 \\
\hline London & & 0.001 & 0.004 & 0.240 & 0.807 & -0.007 & 0.010 \\
\hline South East & & 0.011 & 0.004 & 2.840 & 0.005 & 0.003 & 0.018 \\
\hline South West & & -0.005 & 0.006 & -0.760 & 0.449 & -0.016 & 0.007 \\
\hline Wales & & -0.013 & 0.010 & -1.250 & 0.211 & -0.032 & 0.007 \\
\hline Scotland & & -0.001 & 0.007 & -0.180 & 0.856 & -0.016 & 0.013 \\
\hline $\mathrm{N}$ Ireland & & -0.010 & 0.010 & -1.000 & 0.318 & -0.029 & 0.009 \\
\hline Tories & & 0.012 & 0.006 & 1.980 & 0.048 & 0.000 & 0.024 \\
\hline Labour & & 0.008 & 0.006 & 1.340 & 0.181 & -0.004 & 0.020 \\
\hline Lib Dem & & 0.006 & 0.007 & 0.880 & 0.379 & -0.008 & 0.020 \\
\hline SNP & & 0.016 & 0.016 & 0.980 & 0.327 & -0.016 & 0.048 \\
\hline Green & & 0.044 & 0.007 & 6.040 & 0.000 & 0.030 & 0.058 \\
\hline Other party & & -0.003 & 0.011 & -0.300 & 0.763 & -0.024 & 0.018 \\
\hline Community & & 0.001 & 0.003 & 0.410 & 0.684 & -0.004 & 0.006 \\
\hline Religious & & -0.005 & 0.003 & -1.450 & 0.146 & -0.012 & 0.002 \\
\hline Env Behav & & 0.016 & 0.003 & 4.990 & 0.000 & 0.009 & 0.022 \\
\hline Env Attitude & & 0.015 & 0.008 & 2.040 & 0.041 & 0.001 & 0.030 \\
\hline Renewables & & 0.036 & 0.009 & 3.890 & 0.000 & 0.018 & 0.054 \\
\hline
\end{tabular}


MULTINOMIAL LOGIT

CONSIDERING

Logistic regression

Number of obs

8670

Wald chi2(108)

9356.55

Log likelihood

Prob > chi2

0.0000

$-3464.3872$

Pseudo R2

0.1008

\begin{tabular}{|c|c|c|c|c|c|c|c|}
\hline variable & $\mid$ & $d y / d x$ & $\begin{array}{l}\text { Unconditional } \\
\text { Std. Err. }\end{array}$ & z & $P>|z|$ & [ $95 \%$ & C.I. ] \\
\hline -------- & + & --------- & -------------- & -------- & 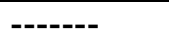 & |--------- & ---------- \\
\hline Sex & & -0.017 & 0.005 & -3.180 & 0.001 & -0.028 & -0.007 \\
\hline Age & & 0.000 & 0.000 & 0.040 & 0.969 & 0.000 & 0.000 \\
\hline Winter fuel & & -0.019 & 0.009 & -2.190 & 0.028 & -0.036 & -0.002 \\
\hline Qualific2 & & 0.013 & 0.016 & 0.810 & 0.418 & -0.019 & 0.045 \\
\hline Qualific3 & & 0.025 & 0.010 & 2.440 & 0.015 & 0.005 & 0.045 \\
\hline Qualific4 & & 0.039 & 0.010 & 3.770 & 0.000 & 0.019 & 0.059 \\
\hline Employed & & 0.006 & 0.007 & 0.910 & 0.360 & -0.007 & 0.019 \\
\hline IncomeQ2 & & 0.002 & 0.008 & 0.250 & 0.800 & -0.014 & 0.019 \\
\hline IncomeQ3 & & 0.001 & 0.008 & 0.180 & 0.860 & -0.015 & 0.018 \\
\hline IncomeQ4 & & 0.004 & 0.008 & 0.530 & 0.598 & -0.012 & 0.021 \\
\hline Tenure & & 0.035 & 0.007 & 4.810 & 0.000 & 0.021 & 0.050 \\
\hline Kids in house & & -0.008 & 0.006 & -1.290 & 0.197 & -0.019 & 0.004 \\
\hline Elec expend & & 0.000 & 0.000 & 2.840 & 0.005 & 0.000 & 0.000 \\
\hline North East & & -0.015 & 0.016 & -0.960 & 0.335 & -0.046 & 0.016 \\
\hline North West & & -0.007 & 0.008 & -0.850 & 0.395 & -0.024 & 0.009 \\
\hline Yorks Humb & & 0.053 & 0.007 & 7.460 & 0.000 & 0.039 & 0.067 \\
\hline E Midlands & & 0.022 & 0.009 & 2.540 & 0.011 & 0.005 & 0.039 \\
\hline W Midlands & & -0.010 & 0.011 & -0.930 & 0.352 & -0.031 & 0.011 \\
\hline E England & & 0.005 & 0.008 & 0.560 & 0.572 & -0.011 & 0.021 \\
\hline London & & -0.001 & 0.007 & -0.090 & 0.926 & -0.014 & 0.013 \\
\hline South East & & -0.019 & 0.008 & -2.440 & 0.015 & -0.034 & -0.004 \\
\hline South West & & -0.019 & 0.010 & -1.910 & 0.056 & -0.038 & 0.000 \\
\hline Wales & & 0.000 & 0.011 & 0.000 & 0.998 & -0.022 & 0.022 \\
\hline Scotland & & -0.008 & 0.011 & -0.740 & 0.458 & -0.028 & 0.013 \\
\hline $\mathrm{N}$ Ireland & & -0.002 & 0.012 & -0.120 & 0.903 & -0.026 & 0.023 \\
\hline Tories & & -0.005 & 0.009 & -0.560 & 0.575 & -0.021 & 0.012 \\
\hline Labour & & -0.004 & 0.008 & -0.520 & 0.603 & -0.020 & 0.011 \\
\hline Lib Dem & & 0.004 & 0.010 & 0.420 & 0.676 & -0.015 & 0.023 \\
\hline SNP & & 0.014 & 0.024 & 0.570 & 0.566 & -0.033 & 0.060 \\
\hline Green & & 0.042 & 0.012 & 3.500 & 0.000 & 0.018 & 0.065 \\
\hline Other party & & -0.012 & 0.014 & -0.880 & 0.377 & -0.039 & 0.015 \\
\hline Community & & 0.001 & 0.003 & 0.250 & 0.803 & -0.006 & 0.008 \\
\hline Religious & & 0.005 & 0.005 & 0.890 & 0.375 & -0.006 & 0.015 \\
\hline Env Behav & & 0.048 & 0.005 & 9.820 & 0.000 & 0.038 & 0.057 \\
\hline Env Attitude & & 0.010 & 0.012 & 0.830 & 0.407 & -0.013 & 0.033 \\
\hline Renewables & & 0.068 & 0.018 & 3.850 & 0.000 & 0.034 & 0.103 \\
\hline
\end{tabular}




\begin{tabular}{|c|c|c|c|c|c|c|c|}
\hline \multicolumn{7}{|c|}{ MULTINOMIAL LOGIT } & \\
\hline \multicolumn{5}{|c|}{ Logistic regression } & \multicolumn{2}{|c|}{$\begin{array}{l}\text { Number of obs } \\
\text { Wald chi2 }(108)\end{array}$} & \multirow{3}{*}{$\begin{array}{l}8670 \\
9356.55 \\
0.0000 \\
0.1008\end{array}$} \\
\hline Log likelihood & & & & & Prob $>c$ & hi2 & \\
\hline-3464.3872 & & & & & Pseudo & & \\
\hline variable & 1 & $d y / d x$ & $\begin{array}{l}\text { Unconditional } \\
\text { Std. Err. }\end{array}$ & $\mathrm{z}$ & $\mathrm{P}>|\mathrm{z}|$ & [ 95\% & C.I. ] \\
\hline --------- & + & ----------- & -------------- & -------- & ------- & ----------- & ----------- \\
\hline Sex & & -0.006 & 0.003 & -1.930 & 0.053 & -0.012 & 0.000 \\
\hline Age & & 0.000 & 0.000 & 1.450 & 0.148 & 0.000 & 0.001 \\
\hline Winter fuel & & -0.001 & 0.005 & -0.270 & 0.786 & -0.011 & 0.008 \\
\hline Qualific2 & & 0.007 & 0.008 & 0.890 & 0.374 & -0.008 & 0.023 \\
\hline Qualific3 & & 0.000 & 0.006 & 0.030 & 0.973 & -0.011 & 0.011 \\
\hline Qualific4 & & 0.009 & 0.006 & 1.710 & 0.086 & -0.001 & 0.020 \\
\hline Employed & & 0.000 & 0.004 & -0.020 & 0.983 & -0.008 & 0.008 \\
\hline IncomeQ2 & & 0.009 & 0.005 & 1.650 & 0.099 & -0.002 & 0.019 \\
\hline IncomeQ3 & & 0.008 & 0.005 & 1.530 & 0.127 & -0.002 & 0.019 \\
\hline IncomeQ4 & & 0.010 & 0.006 & 1.810 & 0.070 & -0.001 & 0.021 \\
\hline Tenure & & 0.006 & 0.004 & 1.440 & 0.149 & -0.002 & 0.014 \\
\hline Kids in house & & 0.004 & 0.003 & 1.210 & 0.227 & -0.003 & 0.011 \\
\hline Elec expend & & 0.000 & 0.000 & 0.420 & 0.673 & 0.000 & 0.000 \\
\hline North East & & -0.010 & 0.012 & -0.830 & 0.405 & -0.033 & 0.013 \\
\hline North West & & -0.001 & 0.005 & -0.230 & 0.819 & -0.010 & 0.008 \\
\hline Yorks Humb & & 0.003 & 0.006 & 0.590 & 0.553 & -0.008 & 0.015 \\
\hline E Midlands & & 0.008 & 0.005 & 1.530 & 0.126 & -0.002 & 0.017 \\
\hline W Midlands & & 0.005 & 0.005 & 0.930 & 0.355 & -0.006 & 0.016 \\
\hline E England & & 0.009 & 0.004 & 2.100 & 0.036 & 0.001 & 0.017 \\
\hline London & & -0.006 & 0.004 & -1.230 & 0.217 & -0.014 & 0.003 \\
\hline South East & & 0.002 & 0.004 & 0.550 & 0.586 & -0.006 & 0.010 \\
\hline South West & & 0.007 & 0.005 & 1.520 & 0.127 & -0.002 & 0.016 \\
\hline Wales & & 0.003 & 0.006 & 0.420 & 0.672 & -0.009 & 0.014 \\
\hline Scotland & & 0.004 & 0.006 & 0.670 & 0.505 & -0.007 & 0.015 \\
\hline $\mathrm{N}$ Ireland & & -0.024 & 0.009 & -2.620 & 0.009 & -0.042 & -0.006 \\
\hline Tories & & 0.004 & 0.006 & 0.720 & 0.472 & -0.007 & 0.016 \\
\hline Labour & & 0.010 & 0.006 & 1.840 & 0.066 & -0.001 & 0.021 \\
\hline Lib Dem & & 0.018 & 0.006 & 3.090 & 0.002 & 0.007 & 0.030 \\
\hline SNP & & -0.003 & 0.019 & -0.170 & 0.862 & -0.042 & 0.035 \\
\hline Green & & 0.017 & 0.008 & 2.090 & 0.036 & 0.001 & 0.033 \\
\hline Other party & & 0.023 & 0.008 & 2.830 & 0.005 & 0.007 & 0.038 \\
\hline Community & & -0.001 & 0.002 & -0.490 & 0.626 & -0.005 & 0.003 \\
\hline Religious & & -0.004 & 0.003 & -1.400 & 0.163 & -0.011 & 0.002 \\
\hline Env Behav & & 0.009 & 0.003 & 3.620 & 0.000 & 0.004 & 0.015 \\
\hline Env Attitude & & 0.011 & 0.007 & 1.570 & 0.117 & -0.003 & 0.025 \\
\hline Renewables & & -0.275 & 0.022 & -12.280 & 0.000 & -0.318 & -0.231 \\
\hline
\end{tabular}




\begin{tabular}{|c|c|c|c|c|c|c|c|}
\hline \multicolumn{8}{|c|}{$\begin{array}{l}\text { MULTINOMIAL LOGIT } \\
\text { NO }\end{array}$} \\
\hline \multicolumn{5}{|c|}{ Logistic regression } & \multicolumn{2}{|c|}{$\begin{array}{l}\text { Number of obs } \\
\text { Wald chi2(108) }\end{array}$} & \multirow{3}{*}{$\begin{array}{l}8670 \\
9356.55 \\
0.0000 \\
0.1008\end{array}$} \\
\hline Log likelihood & & & & & Prob $>c$ & hi2 & \\
\hline-3464.3872 & & & & & Pseudo & & \\
\hline variable & 1 & $d y / d x$ & $\begin{array}{l}\text { Unconditional } \\
\text { Std. Err. }\end{array}$ & $\mathrm{z}$ & $\mathrm{P}>|\mathrm{z}|$ & [ 95\% & C.I. ] \\
\hline --------- & + & ----------- & ------------- & -------- & ------- & \begin{tabular}{|l}
---------- \\
\end{tabular} & ----------- \\
\hline Sex & & 0.028 & 0.007 & 4.060 & 0.000 & 0.014 & 0.041 \\
\hline Age & & 0.000 & 0.000 & -1.350 & 0.176 & -0.001 & 0.000 \\
\hline Winter fuel & & 0.034 & 0.011 & 3.230 & 0.001 & 0.014 & 0.055 \\
\hline Qualific2 & & -0.036 & 0.020 & -1.770 & 0.077 & -0.075 & 0.004 \\
\hline Qualific3 & & -0.039 & 0.013 & -2.900 & 0.004 & -0.065 & -0.013 \\
\hline Qualific4 & & -0.069 & 0.013 & -5.250 & 0.000 & -0.094 & -0.043 \\
\hline Employed & & -0.006 & 0.008 & -0.720 & 0.471 & -0.022 & 0.010 \\
\hline IncomeQ2 & & -0.018 & 0.011 & -1.660 & 0.096 & -0.040 & 0.003 \\
\hline IncomeQ3 & & -0.008 & 0.011 & -0.710 & 0.478 & -0.030 & 0.014 \\
\hline IncomeQ4 & & -0.034 & 0.011 & -3.080 & 0.002 & -0.056 & -0.012 \\
\hline Tenure & & -0.044 & 0.009 & -4.920 & 0.000 & -0.062 & -0.027 \\
\hline Kids in house & & 0.009 & 0.008 & 1.160 & 0.246 & -0.006 & 0.023 \\
\hline Elec expend & & 0.000 & 0.000 & -2.510 & 0.012 & 0.000 & 0.000 \\
\hline North East & & 0.012 & 0.019 & 0.630 & 0.531 & -0.025 & 0.049 \\
\hline North West & & 0.007 & 0.010 & 0.620 & 0.532 & -0.014 & 0.027 \\
\hline Yorks Humb & & -0.044 & 0.012 & -3.720 & 0.000 & -0.067 & -0.021 \\
\hline E Midlands & & -0.047 & 0.011 & -4.350 & 0.000 & -0.069 & -0.026 \\
\hline W Midlands & & 0.020 & 0.014 & 1.410 & 0.159 & -0.008 & 0.047 \\
\hline E England & & -0.024 & 0.010 & -2.470 & 0.013 & -0.044 & -0.005 \\
\hline London & & 0.005 & 0.009 & 0.590 & 0.557 & -0.012 & 0.022 \\
\hline South East & & 0.005 & 0.009 & 0.610 & 0.539 & -0.012 & 0.023 \\
\hline South West & & 0.016 & 0.012 & 1.400 & 0.161 & -0.007 & 0.039 \\
\hline Wales & & 0.010 & 0.015 & 0.670 & 0.502 & -0.019 & 0.039 \\
\hline Scotland & & 0.005 & 0.013 & 0.400 & 0.686 & -0.021 & 0.031 \\
\hline $\mathrm{N}$ Ireland & & 0.035 & 0.017 & 2.080 & 0.038 & 0.002 & 0.068 \\
\hline Tories & & -0.012 & 0.011 & -1.030 & 0.304 & -0.033 & 0.010 \\
\hline Labour & & -0.014 & 0.011 & -1.340 & 0.180 & -0.035 & 0.007 \\
\hline Lib Dem & & -0.029 & 0.013 & -2.290 & 0.022 & -0.053 & -0.004 \\
\hline SNP & & -0.026 & 0.033 & -0.800 & 0.424 & -0.090 & 0.038 \\
\hline Green & & -0.102 & 0.016 & -6.570 & 0.000 & -0.133 & -0.072 \\
\hline Other party & & -0.007 & 0.018 & -0.420 & 0.675 & -0.042 & 0.027 \\
\hline Community & & -0.001 & 0.005 & -0.190 & 0.850 & -0.010 & 0.008 \\
\hline Religious & & 0.005 & 0.007 & 0.700 & 0.484 & -0.009 & 0.018 \\
\hline Env Behav & & -0.073 & 0.006 & -12.250 & 0.000 & -0.085 & -0.061 \\
\hline Env Attitude & & -0.036 & 0.015 & -2.470 & 0.013 & -0.065 & -0.007 \\
\hline Renewables & & 0.170 & 0.029 & 5.880 & 0.000 & 0.113 & 0.227 \\
\hline
\end{tabular}

